\title{
Ambulance Diversion: A Solution or Problem?
}

\author{
Ambulans Diversiyonu: Çözüm mü Yoksa Problem mi? \\ D Mehmet Ali CEYHAN¹, (D Gültekin Günhan DEMiR² \\ 1 University of Health Sciences Turkey, Ankara City Hospital, Clinic of Emergency Medicine, Ankara, Turkey \\ 2 Istanbul Medipol University Faculty of Medicine, Department of Cardiology, Istanbul, Turkey
}

\begin{abstract}
Aim: Ambulance diversion (AD) is defined as redirection of ambulance to an emergency department (ED) different from the initially intended ED with the purpose of both appropriate use of hospital sources for selected patients and relief of ED overcrowding. In the present study, the authors sought to perform a comprehensive analysis of ADs in Ankara, the capital city of Turkey.

Materials and Methods: In this retrospective study, a comprehensive analysis of reasons for AD and the disposition data in the receiving hospital of patients diverted by ambulances of Ankara 112 Emergency Medical Service throughout 2014 (01 January-31 December 2014) was performed.

Results: A total of 174.669 patients were transferred by ambulance to EDs and of those 1.300 ADs (0.74\%) occured. The causes of AD were respectively lack of bed in intensive care unit (ICU), inpatient care ward or EDs (639 AD, 49.1\%), shortage of on-call specialist doctors (242 $A D$, 18.6\%), and insufficent radiology, laboratory equipment and other resources (174 $A D, 13.3 \%$ ).
\end{abstract}

Conclusion: Unavailability of patient beds in EDs, ICUs or inpatient clinics are the most common causes of AD.

Keywords: Ambulance diversion, emergency medicine services, emergency department overcrowding, emergency department

\section{ÖZ}

Amaç: Ambulans diversiyonu (AD) acil servislerin (AS) aşırı yoğunluğunu hafifletmek ve hastane kaynaklarının en uygun şekilde kullanılması amacıyla ambulansla alandan nakledilen seçilmiş bazı hastaların başlangıçta götürülmesi planlanan hastane AS'den farklı bir hastanenin AS'e yeniden yönlendirilmesi olarak tanımlanır. Bu çalışmada Türkiye'nin Başkenti Ankara'da hastanelerin AS'lerinden yapılan AD'larının kapsamlı analizi yapıldı.

Gereç ve Yöntem: Bu retrospektif çalışmada 10cak 2014-31 Aralık 2014 tarihleri arasında Ankara 112 Acil Sağlık Hizmetleri Ambulansları'yla başka hastane acil servisine yönlendirilen hastaları alan hastane sonuçları, AD nedenleri, tanı ve demografik özellikleri araştırıldı.

Bulgular: Toplam 174.669 hasta ambulanslarla hastane AS'lerine nakledildi ve $1.300(\% 0,74)$ AD'u yapıldı. Kadın hastaların sayısı 692 idi (\%53,2). Başlıca hasta $A D$ sebepleri yoğun bakımlarda, hastane servislerinde ve AS'lerinde yer olmaması ( 639 AD, \%49,1), nöbetçi uzman doktorun olmaması (242 AD, \%18,6), ve radyoloji, laboratuvar tetkikleri ve diğer kaynakların yetersizliğiydi $(174 \mathrm{AD}, \% 13,3)$.

Sonuç: AS'lerde, yoğun bakımlarda ve hastane servislerinde yer olmaması AD'nun en sık nedenidir.

Anahtar Kelimeler: Ambulans diversiyon, acil sağlık hizmetleri, acil servis aşırı yoğunluğu, acil servis

\section{INTRODUCTION}

Ambulance diversion (AD) is defined as the redirection of ambulance to an emergency department (ED) different from the initially intended ED'. Lagoe and Jastremski² initially used
$A D$ in patients with minor injuries with the purpose of both appropriate use of hospital sources for selected patients and relief of overcrowding in EDs. Actually, $A D$ is supposed to be used in cases of disasters or overcrowding in EDs for ED surge capacity and redistribution of patients among regional EDs in

Address for Correspondence: Mehmet Ali CEYHAN MD, University of Health Sciences Turkey, Ankara City Hospital, Clinic of Emergency Medicine, Ankara, Turkey Phone: +90538 6273872 E-mail: maceyhan@hotmail.com.tr ORCID ID: orcid.org/0000-0003-0000-0177

Received: 04.10.2020 Accepted: 11.12.2020

๑Copyright 2021 by the Tekirdağ Namık Kemal University Faculty of Medicine / Namık Kemal Medical Journal published by Galenos Publishing House. 
the health service network ${ }^{2,3}$. Although initial utilization of ADs targeted improved health care to overcome conditions such as insufficient hospital resources [computed tomography scanner, blood bank, operating room, intensive care unit (ICU)], staff shortage (trauma team, on-call specialists etc.) and ED overcrowding, inappropriate overuse of AD turned out to be a daily practice and led to increased patient transport time, delays in emergency medical care and negative outcomes in patient health care $^{1,3-6}$.

Determination of frequency, causes and consequences of $A D$ might provide useful information for relevant arrangement and regulations. $A D$ has not been subject to investigation in Turkey so far. The present study aimed to perform a comprehensive and comparative analysis on causes, prevalence, disposition and outcomes of ADs in Ankara, the capital city of Turkey.

\section{MATERIALS AND METHODS}

Management of ED and Emergency Medical Service (EMS) in Turkey is executed according to Emergency Medical Services Regulations (EMSR) ${ }^{7}$. EMSR dictates that all hospitals with emergency healthcare services have to admit and perform necessary interventions to patients transferred by ambulance regardless of the ability to pay or presence of insurance. Temporary interruption of emergency healthcare or AD for patients transferred by ambulance are prohibited. However, if emergency treatment of the patient is not possible in the first admitting hospital and requires transfer to another hospital, transfer to another healthcare facility is permitted after the establishment of required transferred conditions via 112 Ambulance Command Control Center (ACCC) coordination?. In practical aspect, EMSR was not largely followed in the management of patients transferred by ambulance to ED and their transfer to another hospital after AD.

The study was conducted in the assigned work area of Ankara Provincial Directorate of Health (PDH). EMS in Ankara is provided by the Directorate of Emergency Medical Services Department located in the structure of PDH. Stations of 112 Ambulance Services were settled in previously assigned critical points. A crew consisting of paramedic, emergency medicine technician and ambulance driver are on duty basis of 24/7. A few numbers of ambulances include doctor employment and are reserved for complicated cases. Ambulance crew have been trained for Basic Life Support and Advanced Life Support for pediatric and adult population. When 112 emergency line is dialed for emergency medical help, 112 ACCC assigns the nearest ambulance crew to the scene. Patients collected from the scene are transferred to the nearest hospital ED by the discretion of the ambulance crew. AD practice of EDs in Ankara is quite different from the one defined in the literature. After the transfer of the patient collected from the scene to the nearest hospital ED by the discretion of the ambulance crew, patient is evaluated by ED physician without being unloaded from ambulance stretcher and diverted to another hospital after the declaration of reason for not admitting the patient. Following decision for $A D$, the selection of the next hospital is decided by ambulance crew, in some occasions, two or more hospitals are visited for admission to hospital. The most convenient destination is generally found after the ambulation of EDs with the patient.

Ambulance run-sheets include patient name, surname, gender, initial diagnosis, treatment content during transport, the name of the receiving hospital and staff. If $A D$ is decided for the case from the first $E D$, the name of the physician deciding $A D$ and the reason for $A D$ are recorded.

Ambulance run-sheets are collected towards the end of each month in the Committee of Emergency Health Services Coordination (CEHSC) office embodied in Ankara PDH. The data are extracted from ambulance run-sheets as a summary including demographics of the patient, date, the name of the hospital and the physician deciding $A D$, the reason for $A D$ and the name of the receiving hospital after AD. A written form with the information of extracted data is sent to hospitals involved in ADs of the last month by CEHSC. Evaluation Committee of Ambulance Diversion (ECAD) consists of three physicians one of whom is $E D$ staff and evaluates $A D$ by collecting information from the hospital deciding $A D$. ECAD of the receiving hospital evaluates the characteristics, final diagnosis and the disposition of the admitted AD patients. Reports from both hospitals involved in the $A D$ process are sent to CEHSC in hardcopy and digital format. A commission in PDH is gathered each month to interprete ADs performed in the past month.

The present study comprised patients loaded to EMS ground ambulances from scene and diverted by EDs of the first hospital they were transported to another hospital in Ankara in the year 2014 (01 January-31 December 2014). Required data were obtained from CEHSC embodied in Ankara PDH and analyzed in a retrospective fashion. The prevalence and causes of $A D$, patient demographics, final diagnoses, characteristics of the diverting and receiving hospitals, disposition features in the receiving hospital and deaths were investigated.

This study was approved by the Ethical Board of University of Health Sciences Turkey, Ankara Numune Health Training and Research Hospital (Ankara, Turkey; 18.4.2019, decision number: Ethics Committee-19-2669).

\section{Statistical Analysis}

Descriptive statistics were used to summarize clinical characteristics. Median and range were used for expressing 
continuous variables which had abnormal distribution. Normal distribution was tested by the Kolmogorov-Smirnov test. Statistical Package for the Social Sciences (SPSS version 11.0, SPSS Inc., Chicago, IL, USA) was used for analysis.

\section{RESULTS}

Ankara had a population of 5.150.072 in year $2014^{8}$. A total of 174,699 patients were transferred to ED of hospitals in Ankara. A total of 1300 (0.74\%) ADs took place. AD was most frequently used in weekends and out of working hours (974, 74.9\%).
Six-hundred ninety-two patients (53.2\%) were female and the number of patients younger than 18 years was 178 (13.6\%). The number of patients between the ages of 18 and 65 years was 662 (50.9\%). The median age of the study population was 49 years $(100-1)$.

ADs due to internal medical conditions (974 ADs, 74.9\%) were greater than ADs due to surgical conditions (326 ADs, 25\%). The most common causes of medical conditions included shortness of breath (95 ADs, 7.3\%), chest pain (61 ADs, 4.6\%) and cerebrovascular diseases (57 ADs, 4.3\%) (Table 1). Furthermore, the most common surgical conditions

\begin{tabular}{|c|c|c|c|}
\hline & n (\%) & & n (\%) \\
\hline Shortness of breath & $95(7.3)$ & Schizophrenia & $6(0.4)$ \\
\hline Cerebrovascular diseases & $57(4.3)$ & Palpitations & $6(0.4)$ \\
\hline General condition disorder & $53(4.0)$ & Febrile seizure & $6(0.4)$ \\
\hline Fever & $45(3.4)$ & Gas poisoning & $5(0.3)$ \\
\hline Syncope & $44(3.3)$ & Lung cancer & $5(0.3)$ \\
\hline COPD exacerbation & $37(2.8)$ & Imminent abortion & $4(0.3)$ \\
\hline Nausea and vomiting & $35(2.6)$ & Renal colic & $4(0.3)$ \\
\hline Normal delivery & $25(1.9)$ & UTI & $3(0.2)$ \\
\hline Agitation/anxiety & $18(1.3)$ & CKD & $3(0.2)$ \\
\hline Hypertension & $17(1.3)$ & Caustics ingestion & $3(0.2)$ \\
\hline Acute pain & $15(1.1)$ & Prostate cancer & $3(0.2)$ \\
\hline Toxic alcohol consumption & $15(1.1)$ & Tear gases exposure & $2(0.1)$ \\
\hline Gastrointestinal bleeding & $14(1.0)$ & Asthma exacerbations & $2(0.1)$ \\
\hline Dizziness & $13(1.0)$ & Brain cancer & $2(0.1)$ \\
\hline Hypoglycemia & $13(1.0)$ & Ectopic pregnancy & $2(0.1)$ \\
\hline Substance abuse & $13(1.0)$ & Pulmonary edema & $2(0.1)$ \\
\hline Mood disorders & $7(0.5)$ & Senile disorders & $2(0.1)$ \\
\hline Congestive heart failure & $7(0.5)$ & Bipolar disorder & $2(0.1)$ \\
\hline Diarrhea & $6(0.4)$ & Urinary retention & $2(0.1)$ \\
\hline Hyperglycemia & $6(0.4)$ & Other complaintsa ${ }^{a}$ & $45(3.4)$ \\
\hline \multicolumn{3}{|l|}{ Total } & $74(74.9)$ \\
\hline
\end{tabular}


included road accidents (151 ADs, 11.6\%), fall-related injury (95 ADs, 7.3\%) and fight injury (22 ADs, 1.6\%) (Table 2).

The most common cause of $A D$ was unavailability of beds in EDs, ICUs, and inpatient services (622 ADs, 47.8\%) (Table 3).

Unavailability of on-call specialist or a certain clinic with relevant specialization led to 290 (22.3\%) ADs. Neurology (30 ADs $2.3 \%)$, neurosurgery (28 ADs, 2.1\%) and physchiatry (16 $A D s, 1.2 \%$ ) were the main branches causing $A D$, respectively (Table 3).

Unavailability of imaging devices, laboratory tests or other hospital resources led to 176 (13.5\%) ADs. The most common reason among those was broken status or absence of computed tomography (69 ADs, 5.3\%). The number of ADs with undetermined cause or missing data was 114 (8.7\%) (Table 3).

Sociological factors led to $62 \mathrm{ADs}(4.7 \%)$. The most common sociological factor leading to AD was patient's will to be treated in the ED of hospital in which his/her previous treatment was followed (25 ADs, 1.9\%).

The presence of multiple factors such as unavailability of ICU bed, relevant specialist, laboratory tests or other hospital resources was detected in 26 ADs (2\%). Employment of the required surgeon in another surgical operation caused $10 \mathrm{ADs}$ (0.7\%).

A total of $15(1.1 \%)$ AD patients died. Three of them died during ambulance transport, and four died right after arrival to the

Table 2. Surgical complaints of ambulance diversion patients

\begin{tabular}{|l|l|}
\hline & $\mathbf{n}(\mathbf{\%})$ \\
\hline Road accidents & $151(11.6)$ \\
\hline Fill-related injury & $95(7.3)$ \\
\hline Superficial lacerations (except scalp and tendon) & $22(1.6)$ \\
\hline Soft-tissue injury & $9(0.6)$ \\
\hline Head trauma & $5(0.3)$ \\
\hline Fracture & $5(0.3)$ \\
\hline Superficial scalp lacerations & $4(0.3)$ \\
\hline Hand finger amputations & $3(0.2)$ \\
\hline Gunshot injury & $2(0.1)$ \\
\hline Bike accidents & $2(0.1)$ \\
\hline Tendon lacerations & $2(0.1)$ \\
\hline Eye trauma & $1(0.07)$ \\
\hline Dog bites & $1(0.07)$ \\
\hline Blunt thoracic injuries & $1(0.07)$ \\
\hline Shoulder dislocation & $1(0.07)$ \\
\hline Ring tourniquet syndrome & $1(0.07)$ \\
\hline Scrotal trauma & $1(0.07)$ \\
\hline Total & $\mathbf{3 2 6}(\mathbf{2 5 )}$ \\
\hline
\end{tabular}

\section{Table 3. Causes of ambulance diversions}

Unavailability of beds in EDs, intensive care units, inpatient services

$n=1,300(100 \%)$

Unavailability of beds in ED

$622(47.8)$

Unavailability of beds in ICUs or lack of ICU

$385(29.6)$

Unavailability of beds in inpatient services

205 (15.7)

Unavailability of on-call specialist or a certain clinic with relevant specialization

$32(2.4)$

Neurologist or neurology department not available

$290(22.3)$

Neurosurgeon or neurosurgeon department not available

Psychiatrist or psychiatry department not available

$30(2.3)$

Cardiologist or cardiology department not available

Child neurologist not available

Neonatal ICU specialist or neonatal ICU not

available

Thoracic surgeon specialist or thoracic surgeon

department not available

Pulmonologist or pulmonary diseases service not available

Orthopedist not available

Other shortage of on-call specialistsa

$28(2.1)$

Unavailability of imaging devices, laboratory tests or other hospital resources

Broken status or absence of computed tomography

Turning away for multidisciplinary and multidepartmental hospital

Patient registration and automatic control systems break down

Insufficient other resources ${ }^{a}$

Undetermined cause or missing data

Sociological factors

Patient's will to be treated in the ED of hospital

in which his/her previous treatment was

followed

Transfer of patient to wrong hospital by

ambulance

Physical plant breakdown

Diversion requested by a patient or family member

Insurance issues

Admission of two hostile sides in a fight to the same hospital

Other social causes ${ }^{b}$

$16(1.2)$

$15(1.1)$

$14(1.0)$

14 (1.0)

14 (1.09)

$12(0.9)$

$10(0.7)$

$137(10.5)$

176 (13.5)

69 (5.3)

40 (3.0)

21 (1.6)

46 (3.5)

114 (8.7)

62 (4.7)

Presence of multiple factors such as unavailability of intensive care bed, relevant specialist, laboratory tests or other hospital resources

Employment of the required surgeon in another surgical operation caused

25 (1.9)

$9(0.6)$

$8(0.6)$

7 (0.5)

$6(0.4)$

$3(0.2)$

$4(0.3)$

aNumber of causes less than

${ }^{b}$ Causes recorded for once.

ICU: Intensive care unit, ED: Emergency department 
receiving hospital ED (Table 4). One of the patients died after road accident while the others died from medical conditions.

Five hundred three patients (38.6\%) were discharged from the receiving hospital ED and 187 patients (14.3\%) were admitted to inpatient clinics of the receiving hospital. Admissions to ICUs were made in 76 patients (5.8\%); 54 of those $(4.1 \%)$ were admitted to ICUs of the receiving hospital while 22 of those $(1.6 \%)$ were admitted to ICUs of another hospital due to unavailability of ICU bed in the receiving hospital. The disposition of 496 patients (38.1\%) in the receiving hospital could not be determined (Table 4). A small portion of ambulances (52 ADs, 4\%) were diverted for more than once by hospital EDs.

The most common institutions using $A D$ were CommunityGeneral Hospitals (475 ADs, 36.5\%) and University Hospitals (371 ADs, 28.5\%), respectively. The most common institutions receiving $A D s$ were education and research hospitals (858 ADs, $66 \%$ ) and university hospitals (207 ADs, 15.9\%), respectively (Table 5).

Table 4 . The disposition of patients in the receiving hospital

\begin{tabular}{|l|l|}
\hline & $\mathbf{n = 1 , 3 0 0 ~ ( 1 0 0 \% ) ~}$ \\
\hline Discharged from the admitting ED & $503(38.6)$ \\
\hline Receiving hospital could not be determined & $496(38.1)$ \\
\hline $\begin{array}{l}\text { Admitted to inpatient clinics of the } \\
\text { receiving hospital }\end{array}$ & $187(14.3)$ \\
\hline Admitted to ICUs of the receiving hospital & $54(4.1)$ \\
\hline $\begin{array}{l}\text { Admitted to ICUs of another hospital due to } \\
\text { unavailability of ICU bed }\end{array}$ & $22(1.6)$ \\
\hline Left hospital with refusal of treatment & $19(1.4)$ \\
\hline $\begin{array}{l}\text { Died in the receiving hospitals and during } \\
\text { ambulance transport }\end{array}$ & $15(1.1)$ \\
\hline $\begin{array}{l}\text { Transferred to inpatient clinics of other } \\
\text { hospitals due to bed unavailability }\end{array}$ & $3(0.2)$ \\
\hline $\begin{array}{l}\text { Transferred to the hospital with previous } \\
\text { follow-up records }\end{array}$ & $1(0.07)$ \\
\hline ED: Emergency department, ICU: Intensive care unit \\
\hline
\end{tabular}

Table 5. The institutions using ambulance diversion and the institutions receiving ambulance diversions

\begin{tabular}{|l|l|l|}
\hline & $\begin{array}{l}\text { Institutions } \\
\text { performing } \\
\text { ADs } \mathbf{n = 1 , 3 0 0} \\
(\mathbf{1 0 0} \%)\end{array}$ & $\begin{array}{l}\text { Institutions } \\
\text { receiving } \\
\text { ADs } \mathbf{n = 1 , 3 0 0} \\
(\mathbf{1 0 0} \%)\end{array}$ \\
\hline Community-general hospitals & $475(36.5)$ & $119(9.1)$ \\
\hline University hospitals & $371(28.5)$ & $207(15.9)$ \\
\hline Private hospitals & $227(17.4)$ & $80(6.1)$ \\
\hline Education and research hospitals & $149(11.4)$ & $858(66)$ \\
\hline Private university hospitals & $26(2)$ & $36(2.7)$ \\
\hline Multiple ADs & $52(4)$ & \\
\hline AD: Ambulance diversion & & \\
\hline
\end{tabular}

When reports of CEHSC committee assessing appropriate use of ADs were taken into account, 507 ADs (39\%) were deemed appropriate while 365 ADs (28\%) were deemed inappropriate. Appropriate use could not be determined in 428 ADs (32.9\%) due to missing response from hospitals.

\section{DISCUSSION}

The number of patients transferred by ambulance in the study period was greater than the number reported in previous studies; however, $A D$ rates were less than those in the literature ${ }^{1,3,4,9}$. Prohibition of $A D$ in Turkey is the main reason for this finding. Although $A D$ is forbidden in Turkey, inadequate hospital resources mandated the use of $A D$. Furthermore, this appears to reflect serious problems within the hospital system and a failure on the part of local health regulatory agencies to assure access to care as described by law or regulation.

The present study showed that AD was most commonly used in weekends and out of working hours. Similarly, previous studies reported increased use of AD in the evening hours ${ }^{1,3,4}$. The leading cause might be unavailability of many routine health services and on-call specialists in the off-hour time periods.

In consistence with previous reports, the number of patients older than 18 years involved in ADs were greater than the number of pediatric patients ${ }^{1,4}$. Thus, reorganization of EDs providing healthcare service to adult patients might be useful to prevent future ADs.

In countries where $A D$ is legal, eligible conditions and patients for $A D$ are prespecified by $A D$ policies ${ }^{4,7,10,11}$. Since $A D$ is prohibited in Turkey and there is no health policy for $A D$, patients with conditions such as road accident or pregnancy which should not be diverted (even in countries where $A D$ is legal) underwent $A D$. It was also noticed that this situation turned out to be a variable practice of AD between hospitals regardless of the magnitude or severity of the injury. An AD policy with a better and clear definition of cases which should not be diverted might be developed.

In consistence with previous AD reports, unavailability of beds in EDs, ICUs and inpatient clinics were detected as the most common cause for $A D^{3-5,9,12}$. Patients have no restrictions for ED admissions in Turkey and each patient in the ED can seek medical care regardless of the ability to pay. Therefore, there is a sheer amount of admissions to EDs resulting in overcrowding. So, adjustments to increase the number of beds in ICUs and inpatient services are needed to prevent overcrowding of ED and also $A D$.

Death rates were quite lower than the rates reported in previous studies ${ }^{1,3}$. The main underlying reason of this result 
might be less diversion of unstable patients and lower $A D$ rates when compared to those in the literature.

In this study, it was noticed that a portion of ambulances encountered multiple diversions in hospital EDs. Previous studies also reported the involvement of more than one hospital in AD period in the same time frame $\mathrm{e}^{4}$. Selection of the most suitable destination hospital by ambulance crew is a result of lack of a healthy communication among 112 ACCC, ambulance crew and hospital ED directors. Previous studies in the literature pointed out limited coordination among hospital and EMS providers as a contributing factor to diversion problem, thus reconstitution of an effective communication and monitoring infrastructure would establish an effective transport and accurate ED destination of the patient ${ }^{3,13}$.

The majority of ADs were made by community-general hospitals in consistence with previous reports 6 . Unavailability of on-call specialists for 24 hours and limited hospital resources in those hospitals might have played a key role in this setting.

When reports of CEHSC committee assessing appropriate use of ADs were taken into account, only 39\% of ADs were deemed appropriate. Meanwhile, previous reports defined $A D$ as being supposed to be used in cases of disasters or overcrowding in EDs for ED surge capacity and redistribution of patients among regional EDs in the health service network ${ }^{2,3}$. Besides, it is clear that hospitals receiving AD have the capacity to overcome this extra patient burden. However, the main problem might be related to lack of contact (radio or telephone) between the prehospital personnel and hospital EDs. This is not within the standard for almost all EMS systems. Therefore, we believe that constitution of an AD policy with an effective and controllable coordination among 112 ACCC, EMS crew and hospitals is crucial in patient transportation from scene to the most appropriate destination.

Another specific finding reported in our study is the discrepancy of patients supposed to be admitted in ICUs. A total of 205 ADs were done due to unavailability of ICU beds; however, only 76 patients of those were admitted to ICUs in the receiving hospitals. This finding suggests decreased accuracy rate of triage made by the ED physician who diverted the patient or lower decision threshold for ICU admission ending with AD.

\section{Study Limitations}

Although sample size is one of the largest data in this particular topic, retrospective analysis is a limitation. Some of the data including causes of $A D$, patient outcomes and disposition were missing. Similarly, patient demographics of patients transported by private ambulance services were missing. Besides, limitation of AD interpretation with 1 particular year might have diminished the yielding effect of data.

\section{CONCLUSION}

Unavailability of patient beds in EDs, ICUs or inpatient clinics are the most common causes of AD. Therefore, there is an obvious need for more hospital beds. Furthermore, improvement of communication among ACCC, EMS crew and EDs should be targeted for better patient outcomes and optimal management of resources.

\section{Acknowledgements}

We thank Dr. Gamze Babur Güler for her valuable contributions in statistical section.

\section{Ethics}

Ethics Committee Approval: This study was approved by the Ethical Board of University of Health Sciences Turkey, Ankara Numune Health Training and Research Hospital (Ankara, Turkey; 18.4.2019, decision number: Ethics Committee-19-2669).

Informed Consent: Retrospective study.

Peer-review: Externally peer-reviewed.

\section{Authorship Contributions}

Surgical and Medical Practices: M.A.C., G.G.D., Concept: M.A.C., G.G.D., Design: M.A.C., G.G.D., Data Collection or Processing: M.A.C., G.G.D., Analysis or Interpretation: M.A.C., G.G.D., Literature Search: M.A.C., G.G.D., Writing: M.A.C., G.G.D.

Conflict of Interest: No conflict of interest was declared by the authors.

Financial Disclosure: The authors declared that this study received no financial support.

\section{References}

1. Redelmeier DA, Blair PJ, Collins WE. No place to unload: a preliminary analysis of the prevalence, risk factors, and consequences of ambulance diversion. Ann Emerg Med. 1994;23:43-7.

2. Lagoe RJ, Jastremski MS. Relieving overcrowded emergency departments through ambulance diversion. Hosp Top. 1990;68:23-7.

3. Pham JC, Patel R, Millin MG, Kirsch TD, Chanmugam A. The effects of ambulance diversion: a comprehensive review. Acad Emerg Med. 2006;13:1220-7.

4. McCarthy ML, Shore AD, Li G, New J, Scheulen JJ, Tang N, et al. Likelihood of reroute during ambulance diversion periods in central Maryland. Prehosp Emerg Care. 2007;11:408-15.

5. Glushak C, Delbridge TR, Garrison HG. Ambulance diversion. Standards and Clinical Practices Committee, National Association of EMS Physicians. Prehosp Emerg Care. 1997;1:100-3.

6. Sun BC, Mohanty SA, Weiss R, Tadeo R, Hasbrouck M, Koenig W, et al. Effects of hospital closures and hospital characteristics on emergency department ambulance diversion, Los Angeles County, 1998 to 2004. Ann Emerg Med. 2006;47:309-16.

7. Resmi Gazete. Regulation article 12, 13, 14 regarding implementation of EMS in health facilities with inpatient wards. Last Accessed date: March 29, 2020. Available from: http://www.resmigazete.gov.tr/ 


\section{eskiler/2018/02/20180220-4.htm}

8. TÜiK official interactive demographics application. Last Accessed date: March 29, 2020. Available from: https://biruni.tuik.gov.tr/ ilgosterge/?locale=tr

9. Burt CW, McCaig LF, Valverde RH. Analysis of ambulance transports and diversions among US emergency departments. Ann Emerg Med. 2006;47:317-26.

10. Ambulance Diversion Policy. Last Accessed date: March 29, 20. Available from: https://emsa.ca.gov/wp-content/uploads/sites/71/2017/07/5400.pdf

11. San Francisco emergency medical services agency. Last Accessed date: March 29, 2020Available from: https://acidremap.com/sites/files/1/21/5020- diversion-policy.pdf

12. Burt CW, McCaig LF. Staffing, capacity, and ambulance diversion in emergency departments: United States, 2003-04. Advance Data.2006;376:124.

13. El-Masri S, Saddik B. An emergency system to improve ambulance dispatching, ambulance diversion and clinical handover communication-a proposed model. J Med Syst. 2012;36:3917-23. 